\title{
Conceptions of kingship in high-medieval Germany in historiographical perspective
}

\begin{abstract}
Historians of medieval kingship have been influenced by a teleology that sees the development of the secular modern state as inevitable. Therefore the desacralization of kingship is considered a key moment on the path to modern state formation. In Germany, the moment of desacralization has traditionally been identified as 1077, when king Henry IV submitted to Pope Gregory VII at Canossa. Thereafter the spell of Ottonian sacral-kingship was punctured and Henry's twelfthcentury successors were forced to look to Roman law and the support of the princes for legitimation. In this essay, we first examine the historiography of this traditional three-phase paradigm, before introducing some recent scholarship that challenges the paradigm and criticises the universal explanatory power of the demise of sacral kingship as a catch-all reason for change, at the expense of complex political, social and economic factors.
\end{abstract}

\section{Key words}

sacral kingship, desacralization, secularisation, Canossa, Ottonian, Salian, Staufen

\section{$\underline{\text { Main text }}$}

Few historiographical threads are as tightly woven together as the study of monarchies and state formation. Historians of many western nations have sought the origins of modern states in the monarchies of medieval Christendom. The most famous expression of this evolution is perhaps found in the American Joseph Strayer's slender tome On The Medieval Origins of the Modern State (Strayer, 1970). Strayer's thesis concentrated on the English and French realms, for he saw 
the United States as the heir to an Anglo-French tradition. That Germany remained peripheral to Strayer's argument reflects historical as well as historiographical difference, yet as for England and France, the medieval past has been seen as key to understanding Germany's own special path, or Sonderweg, to modern statehood (Barraclough 1947; Reuter 1993; Reuter 2002; Warner 2009). ${ }^{1}$ It is unsurprising then to find that, in addition to the exercise of monarchical power in its economic, military, and judicial manifestations, conceptions of kingship have also tended to be examined through a teleological lens, with the assumption of an inevitable trend towards secular rulership. In Germany, as in England and France, the crown, that symbol of monarchy par excellence, became an abstraction that embodied the state (Hoffmann, 1963; Classen, 1964), while in addition in the Reich the religious aura of the monarchy was transferred to the state, which itself became holy (Koch, 1972; Petersohn, 1994; Weinfurter, 2005; Erkens, 2007): a medieval precursor to the later Holy Roman Empire of the German Nation. This holiness, or sacrality, is central to the historiography of conceptions of kingship in high-medieval Germany and, while many of the debates appear at first glance to be far divorced from the development of the modern nation state, it is imperative to realise that they continue to be embedded in a grand narrative of modernisation and secularisation.

With this overarching teleology in mind we turn to the specific context of highmedieval Germany, which for our purposes encompasses the period between c. 900, when the East Frankish kingdom came into being and c. 1200 when, following the death of Henry VI (1190-8), the Empire descended into civil war. ${ }^{2}$ These centuries witnessed, so the traditional interpretation, a fundamental shift in conceptions of kingship with the pivotal moment arriving in 1077, when Henry IV (1056-1105) came to the pope at Canossa and begged to be readmitted into the Roman Church. These developments, which can be summarised as falling into three phases, embody the broader modernisation and desacralisation paradigm in microcosm. Put simply, the sacral kingship of the Ottonians and early Salians is seen as losing much of its lustre in the crises of the later eleventh century before the Hohenstaufen were able to reburnish the image of monarchy to some extent with recourse to Roman law. In this essay, we shall consider the three phases in turn, before concluding by considering some recent approaches that challenge the established narrative of desacralisation and, indeed, are critical of the very concept of 'sacral kingship'. However, before we 
do so it is first necessary to understand the context in which conceptions of kingship came to be studied by historians of the medieval Reich.

The instigator of interest in conceptions of kingship was Fritz Kern, whose Gottesgnadentum und Widerstandsrecht im früheren Mittelalter, published on the eve of the First World War, set the agenda for subsequent generations of historians to approach the topic of medieval kingship (Kern, 1914). ${ }^{1}$ Indeed, it provided the catalyst for a number of historians of the following generation to turn away from traditional constitutional history (Verfassungsgeschichte) towards the history of ideas (Geistesgeschichte). As liturgical rituals were one means through which ideas about kingship were made visible, coronation liturgies have understandably played a central role in the study of conceptions of medieval kingship (Bak, 1990). Firstly, Percy Ernst Schramm looked at medieval coronations in the context of the symbolism of kingship and also published extensively on royal regalia (e.g. Schramm, 1930, 1935, 1954-6), secondly, Walter Ullmann investigated political and legal theory (e.g. Ullmann, 1955; 1966), and thirdly, Ernst Kantorowicz developed the concept of 'political theology' and was heavily influenced, as was Schramm, by visual and material evidence (e.g. Kantorowicz, 1942; 1957). The rise of the National Socialists ensured these strands remained largely separate as only Schramm remained in an academic post in the German-speaking world by the end of the 1930 s. ${ }^{3}$ Kantorowicz, despite an initial enthusiasm for German nationalism, was forced from his post at Frankfurt and ended up at Berkeley after a short stint at Oxford. ${ }^{4}$ Likewise of Jewish heritage, Ullmann left Austria for England in 1939 and after service in the Second World War became a lecturer at Cambridge. As a result of this the work, particularly of Kantorowicz and his adherents, but to some extent of Ullmann too, appears peripheral to German academic discourse on ideas of kingship. However, although Kantorowicz's 1957 opus The King's Two Bodies was not translated into German until 1990, his thesis that the high middle ages saw an evolution from Christ-centred to law-centred kingship is implicitly accepted, even if he is rarely cited (Fried 1997; Jussen, 2009). Ullmann's emphasis on law is also

\footnotetext{
${ }^{1}$ Kern's work was translated into English by S. B. Chrimes in 1939 under the slightly misleading title Kingship and Law in the Middle Ages.
} 
echoed in Germanophone debates, as is his interest in the relationship between papal and imperial power.

In The King's Two Bodies Kantorowicz discussed the famous frontispiece of the latetenth-century Aachen Gospels, in which a ruler, presumed to be Otto III (983-1002), is presented in striking similarity to contemporary depictions of Christ in majesty. Kantorowicz is far from alone in identifying the purest expression of Christomimetic kingship in the lavish liturgical books of the Ottonian era (e.g. Hoffmann, 1986; MayrHarting, 1991; Weinfurter, 1995; Kuder, 1998). The image of the Ottonians has engendered much interest for two principal and interrelated reasons. The first is an issue of source material - the products of the scriptoria of the Ottonian Reich are undoubtedly dazzling and, along with historical narratives, provide the majority of surviving evidence for the period in the face of a relative paucity of administrative materials. This paucity of administrative documentation has traditionally been seen as reflecting a lack of bureaucratic sophistication on the part of royal government. Thus, we come to the second reason for a concentration on the image of Ottonian kingship: if there was only a rudimentary administrative machinery something else must have held the Ottonian polity together. In the absence of a state apparatus the rulers' sacral aura becomes the glue holding the realm together. This is made particularly apparent when considering the treatment of Ottonian diplomas, which following the pioneering work of Heinrich Fichtenau (Fichtenau, 1957), are studied more for the images and ideas contained in their preambles, for their visual impact and for their performative qualities, than for their actual administrative or legal content (e.g. Rück, 1991; Wolfram, 1995; Stieldorf 2009; on the historiography of the auxilary discipline of diplomatic see Koziol, 2012, pp. 17-37). The administrative structure of the Ottonian realm has its own complicated historiography (Wangerin, 2017), which is beyond the scope of this essay, but it should be recognised that the debate around Ottonian governmental capabilities has a symbiotic relationship to historical approaches to Ottonian sacral kingship.

The extent to which the sacral kingship of the Ottonians was purely a Christian phenomenon has engendered debate. The East Frankish rulers were undoubtedly heirs to a Christian Carolingian tradition modelled on biblical, particularly Davidic, precedents (Ullmann, 1969; Nelson, 1986; Boshof, 2005; Erkens, 2006a). However, 
in the past historians also saw the vestiges of a pagan Germanic warrior sacrality in the Ottonian image and, more recently, influenced by concepts drawn from anthropology, have considered blood ties and charisma to be essential components of Ottonian kingship. Neighbouring disciplines have exercised a large degree of influence on historical approaches to sacral kingship in medieval Europe. Accordingly, discussions of medieval sacral kingship have often taken place in interdisciplinary contexts (e.g. Erkens, 2002) and, while not denying the benefits gained from this engagement, more recent scholarship cautions against comparing medieval Christian kings with rulers of primitive societies. Putting aside this debate for the time being, although the idea of a rigid Ottonian church-system (Reichskirchensystem) no longer dominates (Reuter, 1982), historians are in broad agreement that a close bond with the church was essential to the propagation of the Ottonian image (e.g. Schieffer, 1998; Isabella, 2010). Anticipating the fracturing of this relationship, Tilman Struve described it as a 'structural weakness' in Ottonian theocratic rulership (Struve, 1999, p. 7). From the time of Otto l's imperial coronation at Rome on the Feast of the Purification in 962, the relationship with the papacy was also integral to the strengthening of a theocratic and Christo-centric vision of Ottonian power, which now had an additional Roman-imperial dimension (e.g. Schramm, 1929; Nelson, 1988; Görich, 1993).

Historians identify no conceptual break with the change from the Ottonian to Salian dynasty on the death of Henry II (1002-24). Rather the Ottonian Christo-centric concept of kingship was taken up enthusiastically by the Salians, who continued to use liturgical ceremonial to express an ideology of kingship founded firmly on biblical models. This has been seen, for example, in the fact that the Salians, as the Ottonians and Carolingians had before them, positioned important monarchical events on major liturgical feasts (Huschner, 1993; Sierck 1995), with the Salians displaying a particular affinity for Marian commemorations (Hehl, 1997). When, in December 1046 at the synod of Sutri, Henry III (1028-56) oversaw the deposition of three rival popes before his own candidate, Suidger of Bamberg, was raised to the papal throne a few days later, the ideological framework of German rulership appeared unassailable. Ruling by God's grace (Dei gratia), the claims of the German king-emperors to govern in Christ's image for the good of the whole Christian Church appeared to be no empty boast. This edifice was, however, so the 
traditional interpretation, soon to come crashing down as the relationship between imperial and papal power, once so harmonious rapidly became hostile. Just three decades after Henry III had reigned supreme at Sutri, his son Henry IV was forced to wait barefoot in the snow to gain the forgiveness of Pope Gregory VII at Canossa. Facing opposition from the German princes, who justified their actions as being a response to his excommunication, Henry embarked on a perilous journey across the Alps to pressure Gregory into accepting him back into the Church. This meeting between emperor and pope, which took place at Matilda of Tuscany's hill-top castle in northern Italy, is a moment that has been seen as pivotal in German, if not European, history and looms large in discussions of later Salian kingship.

When, in 2006, Stefan Weinfurter subtitled his popular history of Canossa 'The Disenchantment of the World' (Weinfurter, 2006) he deliberately invoked Max Weber's modernisation paradigm, reminding us once again of the extent to which concepts of kingship have been viewed through the lens of an inevitable path to modernity and secular rulership. ${ }^{5}$ In seeing Canossa as a turning point (Wende) in medieval German history Weinfurter is part of a long tradition, the classic statement being Anton Mayer-Pfannholz's essay: 'Die Wende von Canossa' (Mayer-Pfannholz, 1933). Canossa excites both popular imagination and academic discourse in the German-speaking world. In addition to the publication of Weinfurter's book, 2006 also saw an exhibition held at Paderborn in which the events of 1077 were billed as 'shocking' or 'shaking' the established world order (Stiegemann \& Wemhoff, 2006). It is important to emphasise this popular interest in order to make apparent the wider context in which academic debates surrounding Canossa must be understood. ${ }^{6}$ To an historian from outside of the German tradition such an intense focus on Canossa can be hard to fathom, however, the events at Canossa have held a prominent place in German consciousness for several centuries (Reuter, 2006, p. 147; Hasberg, 2012). Scholarly debate, given fresh impetus by the provocative contributions of Johannes Fried, continues to rage concerning the precise significance of the events at Canossa (e.g. Hoffmann, 2010; Fried, 2008, 2012; Hasberg \& Scheidgen, 2012; Althoff, 2014). However, the effect Henry IV's humiliation on concepts of kingship has, until relatively recently, been accepted without quarrel. For how could a German ruler claim to govern by God's grace and in the image of Christ the king having demonstrated so humiliatingly that his power was inferior to that of the pope? 
Depending on one's sympathies, Canossa was the high or low point of a broader struggle between the papacy and the German emperors 'for the right order in the world' (Tellenbach, 1936, p. 1). Other European monarchies also became embroiled in the so-called Investiture Controversy (Zey, 1998), but the German emperors' singular relationship with Rome inevitably meant that there was a proximity and bitterness to the struggle that was rarely present in the popes' arms'-length interactions with the Capetian monarchs of France or the Norman kings of England. The vehemence of the struggle between Gregory VII and Henry IV is reflected in the survival of a vast quantity of tracts, known collectively as Streitschrifte, in which the ideological basis of imperial and papal power has been seen as being deconstructed and defended (e.g. Leyser, 1965; Robinson, 1978; Schroll \& Riversi, 2016). These tracts have understandably fascinated historians of both the papacy and the German empire and the arguments of Gregory and his acolytes and supporters have been seen as demolishing the very concept of Christian sacral kingship. Rather than as a mediator between clergy and people with his higher status apparent through unction, the German king was argued to be a layman under clerical authority. In response to this sustained and vigorous assault, Henry's supporters were, it has been argued, forced to develop a secularised justification of the emperor's position, thereby in effect conspiring in the dismantling of the emperor's sacral basis (Töpfer, 1982; Struve, 1991; 1999).

The struggle with the papacy was not the only factor in what Leyser termed the 'crisis of medieval Germany' (Leyser, 1983). Opposition from secular and ecclesiastical magnates within the Reich, many of whom, as we have seen, were quick to exploit Henry IV's troubles with the Roman pontiff, was equally threatening to Salian kingship. The election in succession of two anti-kings, Rudolf of Rheinfelden and Hermann of Salm, showed that a number of the German princes were only too happy to accept Gregory's judgement that, despite having been anointed, Henry IV could be deposed. This factor is crucial to understanding one of the pillars that historians have seen as forming a new ideological basis for German kingship as, following decades of turmoil, Frederick Barbarossa again breathed life into the German empire. Linked to the role of the princes in Barbarossa's rise to power, Stefan Weinfurter has argued that a new transpersonal idea of kingship 
developed, as the regnum came to be understood as an abstract institution represented by the princes (Weinfurter, 2005, pp. 195-196). The increasing prominence of the princes as electors underscores their role in the rule of the empire and their participation in the selection of the king provided him with an alternative justification of his position. ${ }^{7}$

The second pillar holding up the edifice of Staufen kingship was the law, which, in the wider context of the twelfth-century renaissance, had a distinctly Roman flavour (Kuttner, 1991). The twelfth-century German monarchs continued to see themselves as heirs to the Roman tradition. Historians have seen the importance of Rome finding visual manifestation on the seals and bullae or the German rulers. During the reign of Frederick Barbarossa a bulla was created on which, for the first time, an actual Roman building can be identified. That the building in question, the Colosseum, is a monument of ancient rather than Christian Rome has led Jürgen Petersohn to stress the increasing importance of the classical Rome to the image of Staufen power (Petersohn, 2010, p. 344). Interest in the ancient past was hardly confined to the Empire, but as Reuter commented, it 'had a sharper political significance in the Reich' (Reuter, 1992, p. 19). This, in part, explains why the revival of Roman law, which also spread far beyond the border of the imperial territories, has been seen as such an important factor in the legitimation of Staufen rule.

As has been recognised, Frederick Barbarossa's interest in Roman law was not entirely novel, although the depth of his engagement with it was new (Appelt, 1962; Fried, 1974, pp. 46-56; Fuhrmann, 1986, p. 147; Struve, 2007). The adherents of Henry V, for example, had used Roman law to argue that emperors had the right to install popes. This proof had been provided by Irnerius, a lawyer from the Bolognese school, and Barbarossa significantly strengthened the link between the imperial court and law school at Bologna with the grant of a privilege, known as the Authentica Habita, in 1155 (Stelzer, 1978). A few years later in November 1158 four Bolognese masters played a prominent role in an assembly at Roncaglia, which aimed at the reorganisation of regalian rights in Italy, and has been seen as epitomising Barbarossa's close relationship with Roman law. The ancient Roman emperor as law-giver thus provided an alternative basis for the image of Staufen power, which 
was not contingent on papal cooperation. Scholars have also seen the Byzantine model of emperorship as influencing the Staufer development of a papstfrei imperial ideology (Koch, 1972, pp. 215-229). The relationship between the Eastern emperor and the head of the Greek Church, in which the patriarch was subordinate to the monarch, offered an alternative archetype for the connection between church and state. Barbarossa's was a Roman Empire of the classical type, not contingent upon his coronation by the pope, and he promulgated 'holy laws' in imitation of ancient rulers such as Justinian (Ullmann, 1975, pp. 92-6). The sacral and 'Christ-centred' kingship of the Ottonians, devalued in the long and bitter struggles of the late eleventh and early twelfth centuries, had been replaced by a more secular, 'lawcentred', conception of imperial rule.

Although isolated denunciations of this traditional desacralisation paradigm can be found earlier, it is really only since the turn of the century that it has come under more sustained attack (e.g. Erkens, 2002; 2006a; 2006b; Hoffmann, 2010; Körntgen 2009; 2013; 2014; Angenendt 2012; Dale, 2016). Interestingly historians who have also worked on the earlier middle ages have been most critical of the paradigm. This undoubtedly reflects increasingly nuanced approaches to Ottonian kingship. David Warner wrote of what he called the 'Presumption of Ottonian Success' (Warner, 2009, pp. 95-101), which, in the context of the medieval German Sonderweg assumed that the Ottonian rulers had begun the construction of a coherent and integrated German state before the later Salian and Staufer rulers reduced the edifice to rubble. Once again, the problem of a teleological approach that explains the development of modern states as being related to the loss of the sacral resources of the monarch rears its head. As sacral kingship has been seen as such an important element in Ottonian success it is inevitable that its weakening becomes a major explanation for the later failure of Salian and Staufer power (Körntgen, 2009). However, hand-in-hand with anthropologically inspired approaches to the reality of Ottonian rule, associated above all with Gerd Althoff (e.g. Althoff, 1997), the image of Ottonian sacral kingship has been re-examined. This exploration has stripped the image of Ottonian kingship of some of its mystique and, as a result, the later Salian and Staufer rulers now appear less overshadowed by the comparison. 
This qualitative relativization is most evident in the work of Franz-Reiner Erkens, who produced a flurry of publications early this century dealing with sacral kingship, which he considers to be a world-wide phenomenon evident across many eras, almost an anthropological constant (Erkens, 2002; 2006a; 2006b). ${ }^{8}$ Accordingly, his monograph on ruler sacrality in the middle ages actually begins with a discussion of ancient Egyptian and Roman kingship, he then traces the development of sacral kingship through the Irish, Visigoths, Merovingians, Carolingians and Ottonians before he concludes with a discussion of the extent to which Canossa precipitated a fundamental change in sacral kingship (Erkens, 2006a). He argues that rather than marking a moment of profound change, the late eleventh century saw a more modest modification of the concept of sacral kingship within the Reich and that many of the elements of sacral kingship found pre-1077 are evident in the twelfth century too. For example, the later Salians and Staufer continued to stress that they were chosen by God, that they ruled as his vicar, and that, through unction, they possessed sacerdotal attributes that set them apart from other laymen. Erkens also points out that there was no monopoly on claiming to be God's deputy even before the Investiture Controversy and that, moreover, the emperors still seemed to be considered as having received their power from God even by those who thought the pope was higher up the food chain (Erkens, 2006b).

Ludger Körntgen pushes the argument further. Throughout his important book on sacral conceptions of kingship found in Ottonian and early Salian art and historiography, he argues for the need to fully contextualise the evidence (Körntgen, 2001). In doing so he draws attention to how nebulous the concept 'sacral kingship' is and how imprecisely it has been used by historians of medieval Germany. He is not the first to recognise the problem: Karl Leyser, for example, expressed his misgivings at using the word 'sacral' to describe the kingship of the Ottonians in 1979, though for Leyser the very imprecision of the word was beneficial as he felt anointing alone could not explain the numinous aura of the Ottonian emperors and that the word 'sacral' encapsulated both ecclesiastical/liturgical aspects and more mystical attributes (Leyser, 1979, p.75). However, if the concept of sacral kingship is so amorphous, does it not lose its explanatory power? This is the argument of Jens Engels, an historian of the French Revolution (the key moment of 'desacralization' in French history), who has criticised the use of the concept of 'sacral kingship' by 
historians (Engels, 1999). He points out that the concept is employed in a variety of ways by ethnologists, sociologists, historians and anthropologists so that there is no consensus as to what 'sacral kingship' actually entails. The term has become a meaningless catch-all phrase to encompass all the aspects of old-style monarchy that do not make sense to the modern rational mind (Engels, 1999, p.8). Building on Engels' work, Körntgen writes of the 'universal explanatory power' (universale Erklärungspotenz) of the demise sacral kingship as a key feature in the development of modern states, so that complex political, social and economic factors pale into insignificance (Körntgen, 2009, p.133).

In keeping with his belief that the evidence for sacral kingship and desacralisation should be fully contextualised, Körntgen has published two important essays on two different source types. Firstly, he has looked at the so-called Streitschrifte and argued that the polemical tracts associated with Henry IV should not be understood as some kind of coherent defence of royal sacrality, but rather as specific responses to specific papal attacks (Körntgen, 2009). He argues that the Investiture Controversy precipitated such a huge outpouring of texts that it is easy to gain the misguided impression that the key issue in the conflict was the religious legitimation of kingship, whereas in fact it was much more about the concrete issue of Henry IV's ability to rule and the justness of Gregory VII's actions against him (Körntgen, 2009, pp.137-155). Körntgen does not deny that Henry's acceptance of Gregory's right to excommunicate him, as the king acknowledged by seeking forgiveness at Canossa in 1077, impacted concepts of kingship. However, he sees this reality as setting boundaries for the sacrality of the monarch, rather than stripping him of sacrality entirely. For Körntgen the Investiture Controversy is thus a moment of discontinuity rather than a turning point or moment of desacralisation (Körntgen, 2009, p.159). In a second contribution Körntgen questions whether a change in the way rulers were depicted in art can be seen as a manifestation of changes in conceptions of kingship (Körntgen, 2014). Specifically, he considers the disappearance of images of rulers from liturgical manuscripts and the development of the more historical ruler imagery associated with the later Salians and Staufer. He argues that this change cannot simply be attributed to the demise of sacral kingship, but needs to be considered in far broader cultural-historical horizons, particularly taking into account changes in aesthetics and commemoratory practices across the high middle ages. Moreover, 
as he points out, it is modern viewers who have seen Ottonian ruler portraits as solely being concerned with projecting royal ideology, when in actual fact they were at least as much about providing a permanent presence for the ruler in a liturgical setting.

Rejection of the desacralization paradigm does not imply a conviction that conceptions of kingship remained static, but that other facets of royal ideology could complement rather than compete with sacral elements of kingship. Thus, Roman law, for example, rather than providing an alternative secular basis for Staufen kingship, in fact strengthened ruler sacrality (Erkens, 2006b, pp.92-7). This argument echoes a wider point made by Janet L. Nelson, a student of Walter Ullmann's, who has argued that it is a mistake to see liturgy and law as mutually exclusive alternatives and has pointed out that throughout the Middle Ages, 'liturgy as a form of political communication...coexisted with law rather than competing with it' (Nelson, 2009, p. 441). The king was Christ's deputy and the deliverer of the law - there was no contradiction in this. Likewise, the increasingly prominent role of the princes does not have to be interpreted as undermining ruler sacrality, rather election by the princes becomes the instrument through which God's will is enacted.

Debates about the ideological basis of royal rule in the German Empire and the significance of Canossa are sure to continue. Going forwards it is apparent that further work to clarify what modern historians mean by 'sacral kingship' and 'desacralization' is required. More attention also needs to be devoted to the ecclesiastical dimension of 'sacral kingship' and to the role of churchmen and institutions in the construction of a sacral image for the king. It is apparent that sacral conceptions of kingship did not simply originate with the monarch himself, and that the sacral legitimacy of the ruler could serve the needs of ambitious bishops and of religious foundations too. Furthermore, as Körntgen's contributions have shown, the evidence for royal ideology must also be more firmly contextualised and factors other than royal sacrality considered when examining changing concepts and practices of kingship. Even Stefan Weinfurter has conceded that Canossa has come to stand for a whole process of change at the turn of the eleventh and twelfth centuries and the alleged desacralization of monarchy cannot explain all these changes (Weinfurter, 2012). 
It would also be beneficial to consider these issues in a broader context. In her recent essay on medieval queenship in this journal, Theresa Earenfight argued that 'the idea of nation as a framework is not useful for studying queenship' as queens were part of an international family and bearers of political and cultural ideas (Earenfight, 2017). The nation also has its limitations for the study of kingship. High medieval kings interacted with the dynasties of neighbouring realms on numerous levels, interactions that only intensified in the twelfth century, not least through the participation of monarchs on the crusades, a phenomenon that surely must be more thoroughly considered in exploring concepts of kingship in this period. As Reuter highlighted, 'people in the Reich were, as elsewhere in Europe, very much aware of what was happening in Other Countries' (Reuter, 1993, pp. 210-211). This is not to suggest that there were no regional differences, but that a pan-European approach better reflects the transmission of cultural and political ideas in the twelfth century. It also offers the opportunity to escape from national historiographies, which have created the strange, and scarcely credible, juxtaposition that German kingship was desacralized in the twelfth century and French kingship not until the eighteenth.

\section{$\underline{\text { References }}$}

Althoff, G. (1997). Spielregeln der Politik im Mittelalter. Kommunikation in Frieden und Fehde. Darmstadt: Primus.

Althoff, G. (2003). Otto III. P. G. Jestice (Trans.). Philadelphia: Penn State University Press.

Althoff, G. (2014). Das Amtsverständnis Gregors VII. und die neue These vom Friedenspakt in Canossa. Frühmittelalterliche Studien, 48, 261-276.

Angenendt (2012). Vor und nach Canossa: rex et sacerdos. In W. Hasberg and H.J. Scheidgen (Eds.) Canossa: Aspekte einer Wende (pp. 141-150). Regensburg: Friedrich Pustet.

Appelt, H. (1962). Friedrich Barbarossa und das römische Recht. Römische Historische Mitteilungen, 5, 18-34.

Arnold, B. (1997). Medieval Germany 500-1300. A Political Interpretation. Basingstoke: Macmillan Press Ltd. 
Bak, J. M. (1990). Introduction: Coronation Studies - Past, Present and Future'. In J. M. Bak (Ed.), Coronations: Medieval and Early Modern Monarchic Ritual (pp. 1-15). Berkeley and Oxford: University of California Press.

Barraclough, G. (1947). Origins of Modern Germany. Oxford: Blackwell.

Benson, R. L. \& Fried, J. (Eds.) (1997). Ernst Kantorowicz: Erträge der Doppeltagung Institute for Advanced Study, Princeton/ Johann Wolfgang Goethe Universität, Frankfurt. Stuttgart: Steiner.

Boshof, E., (2005). Die Vorstellung vom sakralen Königtum in karolingischottonischer Zeit. In F.-R. Erkens (Ed.), Das frühmittelalterliche Königtum: Idelle und religiöse Grundlagen (pp. 331-358). Berlin: DeGruyter.

Cantor, N. F. (1991). Inventing the Middle Ages: The Lives, Works and Ideas of the Great Medievalists of the Twentieth Century. New York: W. Morrow.

Classen, P. (1964). Corona imperii. Die Krone als Inbegriff des römisch-deutschen Reiches im 12. Jahrhundert. In P. Classen and P. Scheibert (Eds.), Festschrift für Percy Ernst Schramm zu seinem 70. Geburtstag (pp. 90-101). Wiesbaden: Steiner.

Dale, J. (2016). Inauguration and Political Liturgy in the Hohenstaufen Empire, 11381215. German History, 34, 191-213.

Earenfight, T. (2017). Medieval Queenship. History Compass, 15.

Engels, J. I. (1999). Das Wesen der Monarchie? Kritische Anmerkungen zum Sakralkönigtum in der Geschichtswissenschaft. Majestas, 7, 3-39.

Erkens, F.-R. (Ed.) (2002). Die Sakralität von Herrschaft: Herrschaftslegitimierung im Wechsel der Zeiten und Räume: funfzehn interdisziplinäre Beiträge zu einem weltweiten und epochübergreifenden Phänomen. Berlin: Akademie.

Erkens, F.-R. (2006a). Herrschersakralität im Mittelalter. Von den Anfängen bis zum Investiturstreit. Stuttgart: Kohlhammer.

Erkens, F.-R. (2006b). Der pia Dei ordinatione rex und die Krise sacral legitimierter Königsherrschaft in spätsalisch-frühstaufischer Zeit. In J. Jarnut and M. Wemhoff (Eds.), Vom Umbruch zur Erneuerung?: Das 11. Un beginnende 12. Jahrhundert; Position der Forschung (pp. 71-101). Munich: Fink.

Erkens, F.-R. (2007). Anmerkungen über die Sakralität des Reiches im späteren Mittelalter. In H. Knüppel, M. Osten, U. Rosenbaum, J. H. Schoeps \& P. Steinbach (Eds.), Wege und Spuren. Verbindungen zwischen Bildung, Wissenschaft, Kultur, Geschichte und Politik. Festschrift für Joachim-Felix Leonhard (pp. 223-240). Berlin: Verlag für Berlin-Brandenburg.

Fichtenau, H. (1957). Arenga. Spätantike und Mittelalter im Spiegel von Urkundenformeln. Mitteillungen des Instituts für Österreichische Geschichtsforschung. Ergänzungsband 18. Graz and Cologne: Böhlau. 
Freed, J. B. (2016). Frederick Barbarossa: The Prince and the Myth. New Haven: Yale University Press.

Fried, J. (1974). Die Entstehung des Juristenstandes im 12. Jahrhundert. Zur sozialen Stellung und politischen Bedeutung gelehrter Juristen aus Bologna und Modena. Cologne \& Vienna: Böhlau.

Fried, J. (1997). Ernst H. Kantorowicz and postwar historiography. German and European perspectives. In R. L Benson and J. Fried, (Eds.), Ernst Kantorowicz. Erträge der Doppeltagung Institute for Advanced Study, Princeton / Johann Wolfgang Goethe-Universität, Frankfurt (pp. 181-201). Stuttgart: Steiner.

Fried, J. (2008). Der Pakt von Canossa. Schritte zur Wirklichkeit durch Erinnerungsanalyse. In W. Hartmann and K. Herbers (Eds.), Die Faszination der Papstgeschichte: Neue Zugänge zum frühen und hohen Mittelalter (pp. 133-198). Cologne: Böhlau.

Fried, J. (2012). Canossa: Entlarvung einer Legende: eine Streitschrift. Berlin: Akademie.

Fuhrmann, H. (1986). Germany in the High Middle Ages c.1050-c.1200. T. Reuter (Trans.). Cambridge: Cambridge University Press.

Gillingham, J. (1971). The Kingdom of Germany in the High Middle Ages, 900-1200. London: Historical Association.

Gillingham, J. (1991). Elective Kingship and the Unity of Medieval Germany. German History, 9, 124-135.

Görich, K. (1993). Otto III. Romanus Saxonicus et Italicus. Kaiserliche Rompolitik und sächsische Historiographie. Sigmaringen: Thorbecke.

Hasberg, W. \& Scheidgen, H.-J. (Eds.) (2012). Canossa: Aspekte einer Wende. Regensburg: Friedrich Pustet.

Hasberg, W. (2012). Nach Canossa sollen wir gehen?: zur Wandlung einer sprachlichen Wendung. In W. Hasberg \& H.-J. Scheidgen (Eds.) Canossa: Aspekte einer Wende, (pp. 15-38). Regensburg: Friedrich Pustet.

Hehl, E.-D. (1997). Maria und das ottonisch-salische Königtum. Urkunden, Liturgie, Bilder. In Historisches Jahrbuch, 117, 271-310.

Hoffmann, H. (1963). Die Krone im hochmittelalterlichen Staatsdenken. In H. M. von Erffa and E. Herget (Eds.), Festschrift für Harald Keller: zum sechzigsten Geburtstag dargebracht von seinen Schülern (pp. 71-85). Darmstadt: Roether.

Hoffmann, H. (1986). Buchkunst und Königtum im ottonischen und frühsalischen Reich. 2 vol. Stuttgart: Hiersemann. 
Hoffmann, H. (2010). Canossa - eine Wende? Deutsches Archiv, 66, 535-569.

Huschner, W. (1993). Kirchenfest und Herrschaftspraxis. Die Regierungszeiten der ersten beiden Kaiser aus liudolfingischem Hause. Zeitschrift für Geschichtswissenschaft, 41, 24-63 and 117-134.

Isabella, G. (2010). Das Sakralkönigtum in Quellen aus ottonischer Zeit: unmittelbarer Bezug zu Gott oder Vermittlung durch die Bischöfe. Frühmittelalterliche Studien, 44, 137-152.

Jarnut, J. \& Wemhoff, M. (Eds.) (2006). Vom Umbruch zur Erneuerung?: Das 11. und beginnende 12. Jahrhundert: Positionen der Forschung. Munich: Fink.

Jussen, B. (2009). The King's Two Bodies Today. Representations, 106, 102-117.

Kantorowicz, E. H. (1942). Laudes Regiae: A Study in Liturgical Acclamations and Medieval Ruler Worship. Berkeley: University of California Press.

Kantorowicz, E. H. (1957). The King's Two Bodies: A Study in Medieval Political Theology. Princeton: Princeton University Press.

Kern, F. (1914). Gottesgnadentum und Widerstandsrecht im früheren Mittelalter. Leipzig: R. F. Koehler.

Koch, G. (1972). Auf dem Wege zum Sacrum Imperium. Studien zur ideologischen Herrschaftsbegründung der deutschen Zentralgewalt im 11. und 12. Jahrhundert. Cologne: Böhlau.

Körntgen, L. (2001). Königsherrschaft und Gottes Gnade. Zu Kontext und Funktion sakraler Vorstellungen in Historiographie und Bildzeugnissen der ottonischfrühsalischen Zeit. Berlin: DeGruyter.

Körntgen, L. (2009). Sakrales Königtum und Entsakralisierung in der Polemik um Heinrich IV. In G. Althoff (Ed.), Heinrich IV. Vorträge und Forschungen 69 (pp.127160) Ostfildern: Thorbecke.

Körntgen, L. (2013). Der Investiturstreit und das Verhältnis von Religion und Politik im Frühmittelalter. In Körntgen, L. \& Waßenhoven, D. (Eds.) Religion und Politik im Mittelalter: Deutschland und England im Vergleich (pp. 89-115). Berlin: DeGruyter.

Körntgen, L. (2014). Herrscherbild im Wandel - Ein Neuansatz in staufischer Zeit? In Görich, K. \& Schmitz-Esser, R. (Eds.) BarbarossaBilder: Entstehungskontexte, Erwartungshorizonte, Verwendungszusammenhänge (pp. 32-45). Regensburg: Schnell \& Steiner.

Koziol, G. (2012). The Politics of memory and identity in Carolingian royal diplomas: the West Frankish kingdom (840-987). Turnhout: Brepols.

Kuder, U. (1998). Die Ottonen in der ottonische Buchmalerei. Identifikation und Ikonographie. In G. Althoff and E. Schubert (Eds.), Herrschaftsrepräsentation im 
ottonischen Sachsen. Vorträge und Forschungen 46 (pp. 137-234). Sigmaringen: Thorbecke.

Kuttner, S. (1991). The Revival of Jurisprudence. In Benson, R. L. \& Constable, G. (Eds.). Renaissance and Renewal in the Twelfth Century (pp. 299-323). Toronto: University of Toronto Press.

Landauer, C. (1994). Ernst Kantorowicz and the Sacralization of the Past. Central European History, 27, 1-25.

Lerner, R. E. (2017). Ernst Kantorowicz: A Life. Princeton: Princeton University Press.

Leyser, K. (1965). The Polemics of the Papal Revolution. In B. Smalley (Ed.), Trends in Medieval Political Thought (pp. 42-62). Oxford: Blackwell.

Leyser, K. (1979). Rule and Conflict in an Early Medieval Society. London: Edward Arnold.

Leyser, K. (1983) The Crisis of Medieval Germany. Proceedings of the British Academy, 68, 410-443.

Mayer-Pfannholz, A. (1933). Die Wende von Canossa. Eine Studie zum Sacrum Imperium. Hochland, 30, 385-404.

Mayr-Harting, H. (1991). Ottonian Book Illumination. An Historical Study. 2 vol. London: Harvey Miller.

Morrison, K. F., (1962). Canossa: A Revision. Traditio, 18, 121-148.

Nelson, J. L. (1986). Politics and Ritual in Early Medieval Europe. London: Hambledon.

Nelson, J. L. (1988). Kingship and Empire. In J. H. Burns (Ed.), The Cambridge History of Political Thought c.350-c.1450 (pp. 211-251). Cambridge: Cambridge University Press.

Nelson, J. L. (2009). Liturgy or law: misconceived alternatives? In Baxter, S., Karkov, C. E., Nelson, J. L. \& Pelteret, D. A. E. (Eds.). Early Medieval Studies in Memory of Patrick Wormald (pp. 433-450). Aldershot: Ashgate.

Oakley, F. (2006). Kingship: The Politics of Enchantment. Oxford: Blackwell.

Oakley. F. (2010). Empty Bottles of Gentilism: Kingship and the Divine Right in Late Antiquity and the Early Middle Ages (to 1050). New Haven: Yale University Press.

Oakley. F. (2012). The Mortgage of the Past: Reshaping the Ancient Political Inheritance (1050-1300). New Haven: Yale University Press. 
Oakley. F. (2015). The Watershed of Modern Politics: Law, Virtue, Kingship and Consent (1300-1650). New Haven: Yale University Press.

Petersohn, J. (1994). Rom und der Reichstitel Sacrum Romanum Imperium. Stuttgart: Steiner.

Petersohn, J. (2003). Deutschprachige Mediävistik in der Emigration. Wirkungen und Folgen des Aderlasses der NS-Zeit. Historische Zeitschrift, 277, 1-60.

Petersohn, J. (2010). Kaisertum und Rom in spätsalischer und staufischer Zeit. Romidee und Rompolitik von Heinrich V. bis Friedrich II. Hannover: Hahnsche Buchhandlung.

Reuter, T. (1982). The 'imperial church system' of the Ottonian and Salian rulers. A reconsideration. The Journal of Ecclesiastical History, 33, 347-374.

Reuter, T. (1991). Germany in the Early Middle Ages c.800-1056. London: Longman.

Reuter, T. (1992). Past, present and no future in the twelfth-century Regnum Teutonicum. In P. Magdalino (Ed.), The Perception of the Past in twelfth-century Europe (pp. 15-36). London: Hambledon.

Reuter, T. (1993). The Medieval German Sonderweg? The Empire and Its Rulers in the High Middle Ages. In A. Duggan (Ed.), Kings and Kingship in Medieval Europe (pp. 179-211). London: King's College London Centre for Late Antique and Medieval Studies.

Reuter, T. (2002). Nur im Westen was Neues? Das Werden prämoderner Staatsformen im europäischen Hochmittelalter. In J. Ehlers (Ed.), Deutschland und der Westen Europas in Mittelalter. Vorträge und Forschungen 56 (pp. 327-351). Ostfildern: Thorbecke.

Reuter, T. (2006). Contextualising Canossa: excommunication, penance, surrender, reconciliation. In J. L. Nelson (Ed.), Medieval Polities and Modern Mentalities (pp. 147-166). Cambridge: Cambridge University Press.

Robinson, I. S. (1978). Authority and Resistance in the Investiture Contest: The Polemical Literature of the late eleventh Century. Manchester: Manchester University Press.

Robinson, I. S. (2000). Henry IV of Germany. Cambridge: Cambridge University Press.

Rogge, J., (2006). Die deutschen Könige im Mittelalter: Wahl und Krönung. Darmstadt: Wissenschaftliche Buchgemeinschaft.

Rück, P. (1991). Die Urkunde als Kunstwerk. In A. von Euw and P. Schreiner (Eds.), Kaiserin Theophanu: Begegnung des Ostens und Westens um die Wende des ersten Jahrtausends. 2 vol. (II: 311-33). Cologne: Das Museum. 
Ruehl, M. A. (2000). 'In This Time Without Emperors': The Politics of Ernst Kantorowicz's Kaiser Friedrich der Zweite Reconsidered. Journal of the Warburg and Courtauld Institutes, 63, 187-242.

Schieffer, R. (1998). Mediator cleri et plebis. Zum geistlichen Einfluß auf Verständnis und Darstellung des ottonischen Königtums. In G. Althoff and E. Schubert (Eds.), Herrschaftsrepräsentation im ottonischen Sachsen. Vorträge und Forschungen 46 (pp. 345-361). Sigmaringen: Thorbecke.

Schramm, P. E. (1929). Kaiser, Rom und Renovatio: Studien und Texte zur Geschichte des römischen Erneuerungsgedankens vom Ende des karolingischen Reiches bis zum Investiturstreit. Berlin and Leipzig: Teubner.

Schramm, P. E. (1930). Die Ordines der mittelalterlichen Kaiserkrönung. Ein Beitrag zur Geschichte des Kaisertums. Archiv für Urkundenforschung, 11, 285-391.

Schramm, P. E. (1935). Die Krönung in Deutschland bis zum Beginn des Salischen Hauses. Zeitschrift der Savigny-Stiftung für Rechtsgeschichte: Kanonistische Abteilung, 24, 184-332.

Schramm, P. E. (1954-6). Herrschaftszeichen und Staatssymbolik. Beiträge zu ihrer Geschiche vom 3. Bis zum 16. Jahrhundert. 3 vols. Stuttgart: Hiersemann.

Schroll, A.-L. \& Riversi, E. (Eds.) (2016). Brief und Kommunikation im Wandel: Medien, Autoren und Kontexte in den Debatten des Investiturstreits. Cologne: Böhlau.

Sierck, M. (1995). Festtag und Politik. Studien zur Tagewahl karolingischer Herrscher. Cologne: Böhlau.

Stelzer, W. (1978). Zum Scholarenprivileg Friedrich Barbarossas (Authentica 'Habita'). Deutsches Archiv, 34, 146-153.

Stiegemann, C. \& Wemhoff, M. (Eds.) (2006). Canossa 1077 - Erschütterung der Welt. Geschichte, Kunst und Kultur am Aufgang der Romanik. 2 vols. Munich: Hirmer.

Stieldorf, A. (2009). Die Magie der Urkunden. Archiv für Diplomatik, 55, 1-32.

Strayer, J. R. (1970). On the Medieval Origins of the Modern State. Princeton: Princeton University Press.

Struve, T. (1991). Die Stellung des Königtums in der politischen Theorie der Salierzeit. In Weinfuter, S. (Ed.), Die Salier und das Reich. 3 vols. (III: 217-244). Sigmaringen: Thorbecke.

Struve, T. (1999). Die Salier und das römische Recht. Ansätze zue Entwicklung einer säkularen Herrschaftstheorie in der Zeit des Investiturstreites. Akademie der Wissenschaften Mainz. Abhandlung der Geistes- und Sozialwissenschaftlichen Klasse, 5, 7-89. 
Struve, T. (2007). Die Rolle des römischen Rechts in der kaiserlichen Theorie vor Roncaglia. In G. Dilcher \& D. Quaglioni (Eds.), Gli inizi del diritto pubblico. L'età de Federico Barbarossa: legislazione e scienza del diritto. Bologna: II Mulino.

Tellenbach, G., (1936). Libertas. Kirche und Weltordnung im Zeitalter des Investiturstreites. Stuttgart: Kohlhammer.

Töpfer, B., (1982). Tendenzen der Entsakralisierung der Herrscherwürde in der Zeit des Invesiturstreites. Jahrbuch für Geschichte des Feudalismus, 6, 164-171.

Ullmann, W. (1955). The Growth of Papal Government in the Middle Ages: A Study in the Ideological Relation of Clerical to Lay Power. London: Methuen.

Ullmann, W. (1966). Principles of Government and Politics in the Middle Ages. London: Methuen.

Ullmann, W. (1969). The Carolingian Renaissance and the Idea of Kingship. London: Meuthen.

Ullmann, W. (1975). Law and Politics in the Middle Ages: An Introduction to the Sources of Medieval Political Ideas. Cambridge: Cambridge University Press.

Waitz, G. (1872). Die Formeln der deutschen Königs- und der römischen Kaiser Krönung vom zehnten bis zum zwölften Jahrhundert. Göttingen: Dieterichschen Buchhandlung.

Wangerin, L. (2017). The Governance of Ottonian Germany in Historiographical Perspective. History Compass, 15.

Warner, D. A. (2009). Reading Ottonian History: The Sonderweg and Other Myths. In P. Skinner (Ed.), Challenging the Boundaries of Medieval History: The Legacy of Timothy Reuter (pp. 81-114). Turnhout: Brepols.

Weinfurter, S. (1995). Sakralkönigtum und Herrschaftsbegründung um die Jahrtausendwende. Die Kaiser Otto III. und Heinrich II. in ihren Bildern. In H. Altrichter (Ed.) Bilder erzählen Geschichte (pp. 47-104). Freiburg im Bresslau: Rombach.

Weinfurter, S. (1999). The Salian Century: Main Currents in an Age of Transition. B. M. Bowlus (Trans.). Philadelphia: Penn State University Press.

Weinfurter, S. (2005). Wie das Reich heilig wurde. In B. Jussen (Ed.), Die Macht des Königs. Herrschaft in Europa vom Frühmittelalter bis in die Neuzeit (pp. 190204 \& 387-390). Munich: C. H. Beck.

Weinfurter, S. (2006). Canossa: Die Entzauberung der Welt. Munich: C. H. Beck. 
Weinfurter, S. (2012). Canossa als Chiffre: von den Möglichkeiten historischen Deutens. In W. Hasberg \& H.-J. Scheidgen (Eds.), Canossa: Aspekte einer Wende (pp. 124-140). Regensburg: Friedrich Pustet.

Wolfram, H. (1995). Political Theory and Narrative in Charters. Viator, 26, 39-52.

Wolfram, H. (2006). Conrad II, 990-1039: Emperor of Three Kingdoms. D. A. Kaiser (Trans.). Philadelphia: Penn State University Press.

Zey, C. (1998). Der sogenannte Investiturstreit. In S. Weinfurter \& F. M. Siefarth (Eds.), Macht und Ordungsvorstellungen im hohen Mittelalter (pp. 89-105). Neuried: Ars Una.

${ }^{1}$ As Reuter has explained, the term Sonderweg was originally coined to describe the course of modern German history after the Enlightenment and to contrast the German experience with that of England, France and the United States. It has been understood both positively to mean that Germany developed in a manner appropriate to its own history and also, given the events of the early twentieth century, as a regretable deviation from a western norm (Reuter, 1993, p. 179).

${ }^{2}$ For an excellent short introduction to the history of medieval Germany in these centuries see Gillingham, 1971. Other English overviews include Fuhrmann, 1986; Reuter, 1991; Arnold, 1997. Some of the German kings of this period have been the subject of English-language biographies, which are included in the bibliography. ${ }^{3}$ For a discussion of the emigration of a number of German and Austrian medieval historians during the Nazi period see Petersohn, 2003.

${ }^{4}$ Schramm and Kantorowicz were famously caricatured as 'Nazi Twins' in Cantor, 1991. Partly in response to this, the study of Kantorowicz himself has become practically a field in its own right (e.g. Landauer, 1995; Benson \& Fried 1997; Ruehl, 2000; Lerner, 2017).

${ }^{5}$ A discussion of Weber's theory of rationalization, complicated as it is by the complex editorial history of his oeuvre, lies beyond the scope of this essay, but, broadly, Weber used the concept of disenchantment to describe modernised, bureaucratised and secularised western society.

${ }^{6}$ An academic volume of essays was also published in conjunction with the exhibition: (Jarnut \& Wemhoff, 2006).

7 The elective nature of German monarchy is seen as a key element in the medieval Sonderweg. For a recent introduction in German see Rogge, 2006. The best treatment of the phenomenon in English remains Gillingham, 1991.

${ }^{8}$ Erkens is hardly alone in viewing 'sacral kingship' in this way. See, for example, Francis Oakley's short book on the subject (Oakley, 2006) and his recent threevolume study, which provides an elegant, though rather old-fashioned, grand narrative of the development of western political thought (Oakley, 2010;2012; 2015). 